\title{
Judicial Review towards Financial Status and Levies Management Mechanism of the Financial Services Authority (FSA) within the Republic of Indonesia's Financial System
}

\author{
Demson Tiopan'; Dwi Haryati ${ }^{2}$ \\ 1. Faculty of Law, Maranatha Christian University \\ 2. Faculty of Law, Gadjah Mada University \\ dtiopans@gmail.com \\ Submitted: 2018-03-01; Reviewed: 2018-03-20; Accepted: 2018-04-30
}

\begin{abstract}
Penelitian ini bertujuan untuk mengetahui, meneliti dan mengkaji status keuangan OJK dalam sistem keuangan Negara Republik Indonesia, serta untuk mengetahui dan mengkaji mekanisme pengelolaan pungutan yang dilakukan oleh OJK dikaitkan dengan asas akuntabilitas dan proporsionalitas. Jenis penelitian yang digunakan yakni penelitian hukum normatif dengan didukung penelitian empiris untuk menjawab rumusan masalah pertama dan kedua. Jenis data dalam penelitian ini menggunakan dua jenis data, yaitu menggunakan data primer dan sekunder, di mana data primer digunakan untuk mendukung penelitian data sekunder. Sementara itu, teknik pengumpulan data yang digunakan adalah teknik studi dokumenter dan wawancara langsung. Berdasarkan hasil penelitian dalam pembahasan maka dapat dikatakan; Pertama, hasil penelitian menunjukkan bahwa status keuangan OJK dilakukan melalui pungutan terhadap industri keuangan merupakan keuangan negara. Hal ini dapat dilihat dari pengertian keuangan negara dalam UU Keuangan Negara dibandingkan dengan sistem keuangan yang dilakukan OJK. Kedua, mekanisme pengelolaan keuangan OJK dalam pungutan dan pengawasan sudah memenuhi asas akuntabilitas dan proposionalitas. Akan tetapi mengenai pelaporan belum sepenuhnya memenuhi asas proporsionalitas karena masih belum terserapnya anggaran OJK secara maksimal yang menunjukkan masih banyak kewajiban OJK yang seharusnya dilakukan belum terlaksana.
\end{abstract}

Keywords: Asas Akuntabilitas; Asas Proporsionalitas; Otoritas Jasa Keuangan; Status Keuangan.

\section{INTRODUCTION}

Since the crisis from the year 1997 to 1998 , Indonesia has tried to recover by issuing new regulations. One of them is to reinforce Indonesian banking system. Bank Indonesia as the central bank have had its surveillance system toward other banks in Indonesia reinforced. The bank cautiousness principle has been emphasized in the providing of credits so as not to cause another bad credit which has a systemic impact. The reinforcement of 
Bank Indonesia didn't outright left the Indonesian government and parliament satisfied in their effort for the people's safety and prosperity. The government and the parliament felt the necessity to move the banking surveillance function from the central bank to an independent institution outside the central bank. The separation of function is declared in the $34^{\text {th }}$ Article of Act No. 3 of 2004 regarding the Amendment of Act Number 23 of 1999 regarding Bank Indonesia which gave birth to a new institution called the Financial Service Authority, better known as the FSA.

In the execution of its function and duty, the FSA requires a large amount of funds. Estimation of the cost of forming and operating the FSA according the academic review by the Economy and Business Faculty Team of UGM and UI goes up to 20.252 trillion $^{1}$, while according the FSA's Chief of Commissioner Council, Muliaman D. Hadad, the FSA's requirement for the budget year of 2014 is estimated to be more than 2 trillions. $^{2}$ In order to fulfill the necessity, Article 34 verse (2) of Act Number 21 of 2011 regarding the FSA states that the funds for FSA came from the Nation's Income and Expenditure Budget (APBN), and/or from parties working in the financial service sector. The explanation of this Article wills that the FSA funding basically comes from collections, therefore, the funding of the FSA is independent in nature, but as long as the FSA still unable to provide itself, the cost will be imposed to the APBN.

The FSA's finance can also be seen in the general regulation regarding the

\footnotetext{
${ }^{1}$ Tim UGM dan UI, Alternatif Struktur OJK yang Optimun, Jakarta: UGM dan UI, 2010, p.152.
}

definition of financial system in Indonesia as written in Article 1 number 1, Article 2, and the third paragraph of general explanation in Act number 17 of 2003 regarding the Nation's Finance. The Nation's vast finance can be grouped into fiscal management subfield, monetary management subfield, and the separated national wealth management subfield. The nation's finance definition explains that the FSA's finance that comes from APBN in a part of the nation's finance, but it caused doubt regarding the collection done by the FSA. From the view of Act No. 1 of 2004 regarding the National Treasury, the collection done by the FSA seems against the definition of the Nation's Cash, where the Act of National Treasury defines the Nation's Cash as the storage of the nation's money which is regulated by the Minister of Finance as the National General Treasurer to store all national income and expenditure. The collection done by the FSA doesn't match with such definition. Exceptions to the collection management can only be done by the Regional Government that is included to the Regional Cash and the General Service Board as regulated by Article XII Act number 1 of 2004 regarding National Treasury.

Finance received by the FSA has made its financial status unclear as the two sources is accepted by the FSA. On one side, the Law demands the FSA to undertake collection from the financial industry, on the other side, the Nation's money as defined by the National Finance Act also goes into the system. This goes along with the statement of the Professor of 
Public Finance from the University of Indonesia, Arifin P. Soeria Atmadja which said: ${ }^{3}$

"On the other side, it (FSA) is an institution that still utilizes the APBN. If it's independent, it's a legal entity of its own, so as the money that gets in there belongs to the FSA's finance, not the National Finance. If the FSA isn't classified as a legal entity and also emphasized as an institution that executes governmental matters, then the financial legal status of the FSA's collection from the financial service executants. Seen from the law, the FSA can accept, manage, and administer such collection withow storing beforehand according the cash principle."

Based on that fact, the author is interested to review what the financial status of the FSA is in the financial system of the Indonesian Republic and the collection management mechanism done by the FSA connected by the accountability and proportionality principle.

\section{DISCUSSION}

Financial Service Authority's Financial Status in the National Financial System

According to the statement of Yuzirwan, Head of the FSA's Finance, in order to execute its duty and function, the FSA uses the APBN and also its own collection as stated by the Act of the FSA. In 2013 and 2014, the FSA used funds solely from the APBN, in $2015,51 \%$ of the funds came from the collection and $49 \%$ came from the APBN, and in 2016 the FSA used 100\%

\footnotetext{
${ }^{3}$ Fathan Qorib, 2013, "Pakar Pertanyakan Status Keuangan OJK”, http://www.hukumonline.com/ , accessed 8 Oktober 2015.

4 Zainal Arifin Mochtar, Penataan Lembaga Negara Independen Setelah Perubahan Undang-
}

funds from the collection from the financial industry. The usage of the APBN funds and collection is linked to the FSA's financial status. In order to see the FSA as an independent institution, one must compare the traits of independent institutions. According to Zainal Arifin Mochtar ${ }^{4}$, the theoretical traits that become the foundation of an independent state institution, can be listed into several traits. First, an institution that is created and placed doesn't become part of an existing authority branch even though at the same time it becomes an independent institution that undertakes duties once held by the government. $^{5}$

In the governmental structure, the FSA is not under any institution, however, according to the FSA Structure regulated in Chapter IV Article 10 to 25 of Act number 21 of 2011 regarding the FSA, there is a governmental institution inserted into the FSA's structure which is an ex-officio member from the Department of Finance which is comparable as a first echelon officer of the Department of Finance.

Institutionally, the FSA's position outside the government is understood as being unattached and not becoming a part of the government authority, however it doesn't deny the possibility of the existence of governmental power elements, since in essence, the FSA is in the financial service sector that is related with other authority such as in terms of fiscal and monetary issues.

Second, its members are accepted through selection process and not through

Undang Dasar 1945, Disertasi, Yogyakarta: Universitas Gadjah Mada, Yogyakarta, p.106-107.

${ }^{5}$ Ibid. 
political appoint process. ${ }^{6}$ Article 11 clause (1) states that Members of the Commissioner Council as defined in Article 10 clause (4) letter a to $g$ are chosen by the Parliament based on candidates recommended by the President. In clause (2) it is stated that the selection and appointment of the candidates for the Members of the Commissioner Council which is to be suggested to the President as stated in clause (1) is undertaken by the Selection Committee formed by the President's Decree.

Third, the processes of selection and discharge can only be done based on the mechanism determined by the law it is based from. ${ }^{7}$ The selection and discharge processes itself is regulated in Act No. 21 of 2011 regarding the FSA. So far the appointment has complied to the procedure, however the process of discharge has not been done due to the FSA still newly formed and its Commissioner Member's service period has not expired.

Fourth, although the FSA holds power as a national instrument, its deliberation process is very strong, thus the membership, process of selection and reporting of performance are done close to the people as the nations sovereign, both directly towards the society and indirectly through the parliament. ${ }^{8}$ Article 38 clause (5) regarding the FSA obligates the disclosure of three-month activity reports as stated in clause (2) to the Parliament as a form of accountability to the people. This shows that the FSA is directly responsible to the people through the Parliament.

\footnotetext{
${ }^{6}$ Ibid.

${ }^{7}$ Ibid.

${ }^{8}$ Ibid.

${ }^{9}$ Interview with Head of OJK Admission Division Mr. Yuzirwan dated June 16, 2016
}

Furthermore, the FSA always issued yearly financial reports to the people by uploading them to its official website as an effort of accountability. ${ }^{9}$

Fifth, the nature of FSA's leadership is collegial and collective in every institutional decision regarding its duty and function. ${ }^{10}$ As elaborated above that there is a Commissioner Council member that is the head and a member at the same time. The regulation of such relationship between members shows a collective collegial leadership.

Sixth, the FSA is not a main national institution in the sense that without its existence the nation cannot function. However, it doesn't mean that it isn't necessary for the FSA to exist. Its existence is still important due to the demands of a transitional time and the increasingly complex administrative necessities. ${ }^{11}$ With or without the FSA, Indonesia can still function. But without the President, Indonesia can't function. However, the FSA is important in the effort to watch over the costing world in Indonesia.

Seventh, the FSA has a more (devolutif) authority which is self regulated in the sense that it can issue its own regulations that are also applied generally. ${ }^{12}$ Article 21 states that in undertaking the authority stated in Article 6, the Commissioner Council establishes the FSA Regulation, the Commissioner Council Regulation, and/or the Commissioner Council Decree. Article 1 number 11 explains that the FSA Regulation is a written regulation established by the
${ }^{10}$ Zainal Arifin Mochtar, Op.Cit.
${ }^{11}$ Ibid.
${ }^{12}$ Ibid.

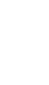


Commissioner Council, generally binding, and is made law in the Fascicle of the Republic Nation of Indonesia. Thus the FSA has authority that applies generally for the costing world.

Eighth, the FSA has a legitimate base on the constitution and/or law. ${ }^{13}$ In the sense that there is a legitimate base on the constitution, although later it is formed by just an act for an institution that exist in the constitution. The FSA itself is formed on the basis of Article 34 of Act number 3 of 2004 regarding the Amendments on Act number 23 of 199 regarding the Bank of Indonesia that states: the duty to supervise the Bank will be done by an independent financial service sector surveillance institution, formed by the Law. This Article later gives birth to the FSA institution.

Afterwards, the FSA has Objectives and Functions. Article 4 of the Act regarding the FSA states that one of the objectives of the FSA's forming is to protect the interest of the consumer and the people. This fact goes in synch with the duty of the government mandated in the fourth paragraph of the 1945 Constitution's Preamble whereas one of the purpose of the nation is to protect all the people of Indonesia and their entire native land and to advance public welfare.

Article 2 of Act no. 17 of 2003 regarding the National Finance formulates the definition of the national finance, from that definition there are some meanings that has connection to the FSA's financial which are:

1. The obligation of the nation to undertake the national

\footnotetext{
13 Ibid.

14 Muchlis Hamdi, Naskah Akademik Rancangan Undang-Undang (RUU) Tentang Hubungan
}

government's public service duty and to pay third parties' bill; the FSA as an institution formed by the law and part of the national organization has duties and functions, one of them is to protect the interest of the consumer and the people as stated by the Article 4 of the Law of the FSA. Given a broader definition, it means that the establishment of this nation is meant to establish the welfare of its people and the interest of the nation itself. From this definition, the governmental system can be literally defined as a form of relationship between national institution in establishing national powers for the interest of said nation for the purpose of fulfilling national objectives which one of them is to protect the interest of the general public, ${ }^{14}$ therefore the FSA, in terms of its duties and function has undertaken the establishment of the national government, and thus, its financial is still in the scope of national finance.

2. National income; the definition of national income is the money that goes into the National Cash. The Law of National Treasury defines the National Cash itself as the storage of the nation's money that is determined by the Minister of Finance as the Nation's General Treasurer to store all national income and pay all national expenditure. According to Article
Kewenangan Pemerintah Pusat dan Daerah, Jakarta: BPHN, 2012, p.10. 
34 of the Law of the FSA, the collection done by the FSA is done independently by the FSA, and thus not included as the national cash. CHAPTER XII of Act no. 1 of 2004 the National Treasury regulates exception that can be done toward collection managements not done by the Minister of Finance which only be done by the Regional Government that goes into the Regional Cash and Public Service Agency.

Analogous to the PPK-BLU the FSA's financial management pattern is the same as that of a public service agency because it is flexible, proved in Article 35 of the Law of FSA that the FSA can manage its finance independently and determine standards in the purchase of goods and services. Even the FSA can buy government bonds and deposit its money to earn profit to be later used for FSA's operational. ${ }^{15}$

Article 2 of PP PK-BLU states that BLU has an objective to increase service to the society in order to improve public welfare and advance intellectual life of the people by giving flexibility in financial management base on economical and productivity principle and to apply healthy business practice. One of FSA's objectives is to improve service to the society, especially protection in the financial industry. It can be seen on the Law of FSA Article 4 that states the objective of FSA's forming, one of which is so that the entire activity in the financial system sector is established in an orderly, fair, transparent, and accountable fashion; capable of realizing a financial system that has continuous and stable growth; and capable of protecting the interests of consumers and society.

3. National/regional wealth that is managed independently or by other party in the form of money, stock, receivables, goods, and other rights that can be valued with money, including wealth separated to the national/regional corporation; the forming of FSA originally used APBN (Article 34 Law of FSA), thus if it is interpreted from the definition the National Finance, the FSA is still within the scope of the nation's finance because its assets are national wealth managed by the FSA in the form of money and goods. Although later asset increase came from collection, but the entirety of FSA's asset is mixed with funding from APBN.

4. The wealth of other parties controlled by the government in the framework of the administration of governmental duties and / or public interest; wealth of other parties obtained by using the facilities provided by the government. FSA assets are controlled by the Government due to FSA financial control in the FSA Law conducted by BPK or public accountant

${ }^{15}$ Interview with Head of OJK Admission Division Mr. Yuzirwan dated June 16, 2016 
appointed by BPK (Article 38 paragraph (8) of the Law of the FSA), although the levies are independent. FSA also performs general government duties where the purpose of established FSA to keep the financial industry in order to run properly so as to benefit and protect the public in general as listed in Article 4 of of the Law of the FSA.

It is also necessary to review the correlation between the definition of national finance and the FSA's financial from the general description from the third paragraph of Act number 17 of 2003 regarding the National Financial that formulized national finance from various approaches, which are:

1. Object; what is meant as the Nation's Financial encompasses all national rights and obligations that can be valued with money, including policy and activities in the field of fiscal, monetary, and the management of separated national wealth, also everything, whether it is money or goods that can be in the possession of the nation in lieu of the establishment of said rights and obligations. If we look at the BI's capital, it is clearly explained by Article 6 clause (1) of Act number 3 of 2004 regarding the Amendments on Act number 23 of 1999 regarding the Bank of Indonesia that states that the Capital of Bank of Indonesia as stated in this clause comes from separated national wealth, which is the sum of capital, public reserve, purposive reserve, and part of profit which has not divided according to Act number 13 of 1968 regarding the Central Bank before this Act is enacted. If the FSA's regulation is viewed, the FSA doesn't explicitly stated as a separated national finance.

2. Subject; what is meant as the Nation's financial encompasses all object as mentioned above that belongs to the nation, and/or under authority of the Central Government, Regional Government, National / Regional Corporation, and other agency that is connected to the nation's finance. The FSA's wealth is under Government's authority because the surveillance of the FSA's finance according the Law of the FSA is done by the Audit Board of Indonesia (BPK) (Article 38 clause (8) Law of the FSA), although the collection is independent in nature. The FSA also undertake public government duty which the objective of the FSA's forming is to keep the financial industry working well in order to benefit and protect public society as written in Article 4 Law of the FSA.

3. Process; what is meant as the Nation's financial encompasses all sequences of activity connected to object management as mentioned from the formulation of policy and decision making until accountability checking. This is not applied in the FSA's finance management. Article 17 clause (4) of the President's Decree regarding 
the FSA states that an authority relation exists between the FSA and the Minister of Finance in terms of arranging the scale of collections. The arranging of the collection shows that the policy formulation regarding the collection cannot abruptly be done by FSA. The FSA's accountability also involves the Parliament element as meant by article 38 Law of the FSA.

4. Objectives; what is meant as the Nation's financial encompasses all policies, activities and legal connections related to the possession and/or authority of objects as mention above in order to establish national government. The FSA as an independent institution does not undertake the establishment of government if the government is understood as the central government. But if it is defined in a broader sense where the establishment of government is to undertake the nation's objective in which one of the is to protect the interest of public society, then the FSA is undertaking the establishment of national government and thus its finance is still in the scope of national finance. The objective is to protect the society which is the consumer of Banking institutions, Capital Market, Insurance, and other financial service institution. This goes in line with the Government's duty mandated in the fourth paragraph of 1945 Constitution's preamble which states that one of the nation's objective is to protect all the people of Indonesia and their entire native land and to advance public welfare.

Afterward, seen from the Regulation of the Indonesian Republic Minister of Finance number 235/PMK.05/2011 regarding the Accounting System and Other Agency's Financial Reporting, Article 1 number 6 explained that Other Agency Unit later mentioned as UBL is an organization unit which is an inseparable national wealth that is formed with the purpose to establish certain program and activity mandated by legislation and/or support ministry/institutional function directly to a certain Ministry/Institutional Leadership.

\section{Conformity of Collection Management} Done by the FSA Related to the Accountability and Proportionality Principle.

1. FSA Collection Mechanism

According to FSA's Income Section Head Yuzirwan ${ }^{16}$, FSA's collection started from the Department of Finance's income section coordinating with the entire financial service surveyor within the commissioner and each department to collect funds. The collection done in 2015 will be used for the 2016 budget year. The FSA made expenditure plans and income targets from the collection. According to Article 35 Law of the FSA, the FSA's budget is used to fund operational activity, administrative activity, asset providing and other support activities. Afterwards, the

${ }^{16}$ Interview with Head of OJK Admission Division 
Budget and its usage to fund operational activity, administrative activity, asset providing and other support activities are appointed based on reasonable standard in the financial service sector and excluded from the general cost standards, goods and service providing process and remuneration system as regulated by legislative rules related to the APBN. According to Yuzirwan, the Budget is arranged by the Strategic, Budget, and Performance Management Committee whose duty is to see the directions from superiors and requirements of every subordinate unit. Then it is appointed by the FSA's Commissioner Council and Remuneration Committee through the Council Meeting. After it is appointed, the budget is recommended to the Parliament that is in charge of finance and banking to earn approval as explain in Article 36 Law of the FSA.

Collection done by the FSA is not rashly appointed by the FSA, it is done according to the Government's Regulation as Article 5 clause (2) Governmental Regulation no. 11 of 2014 regarding the FSA's Collection states that the type, unit, and scale of FSA's Collection as meant in clause (1) is appointed in the Appendix which is an inseparable part of the Governmental Regulation.

In its collection management mechanism, sometimes the FSA adjust the collection with the condition of the financial industry that is being collected as written in Article 15 clause (1) Governmental Regulation no. 11 of 2014 regarding the FSA's Collection. The usage

${ }^{17}$ Rooseno dan Tim, Penelitian Hukum tentang Akuntabilitas Pendanaan Partai Politik Dalam Undang-Undang Nomor 2 Tahun 2011, Jakarta: of collection to fund asset purchasing refers to Financial Service Authority Commissioner Council's Form Letter Number 8/SEDK.02/2015 regarding Fixed Asset and Intangible Asset Accounting. Regulation regarding this asset usage is strictly regulated in said rule's conditions. According to the opinion of Jabra and Devi, Administrative/Organization.

Accountability is the Accountability between the official in charge with his/her subordinates in a clear hierarchal relation. ${ }^{17}$ Within the FSA's collection management mechanism there is a hierarchal relation between structures within the FSA such as the income section of Financial Department coordinating with all financial service surveyor. Then the MSAK Committee is formed to look for guidance from the superiors and oversee the requirement of every unit below which in the end will be appointed by the FSA's Commissioner Council and Remuneration Committee through the Council Meeting. According to the legislative rule above, the FSA has fulfilled the expected accountability principle. Arifin P. Soeriaatmadja gave explainataion of the Proportionality Principle; the allocation of budget which is undertaken proportionally to the institutional functions according to priority levels and objective pursued. This proportionally done allocation is seen from the FSA's collection which started from the income section Financial Department who coordinates with all financial service surveyor within each commissioner and department to collect funds. Collection done in 2015 will be used for the budget

Badan Pembinaan Hukum Nasional Kementrian Hukum dan HAM, 2014, p. 6-7. 
year 2016. The budget is arranged by the MSAK Committee, who is tasked to look for guidance from the superiors and oversee the requirement of every unit below which will be appointed by the FSA's Commissioner Council and Remuneration Committee through the Council Meeting.

2. The FSA's Internal Surveillance on Collections Mechanism.

As explained before, the FSA is under the surveillance of the Parliament, specifically Commission XI. ${ }^{18}$ Furthermore, there are surveillance that is internal in nature. Internal Audit is the realization of the mandate stated in Article 1 Number 22 Law of the FSA that explains that the Audit Council is the Commissioner Council's support organ who is task to perform evaluation on the FSA's job undertaking and establish FSA's audit standards and risk management. The FSA's internal audit function is implemented into the Internal Audit, Risk Management, and Quality Control Section (AIMRPK). The insurance and consultation activities are done independently and objectively by the AIMRPK in order to give suggestions to improve the system as an added value of the FSA's objective pursuit. The aud ${ }^{19}$ it standard used by the PSA refers to the internationally accepted standard which is the International Professional Practice Framework (IPPF) issue by the Institute of Internal Auditor (IIA). Using standards refered to the IPPF is meant so that there is

\footnotetext{
18 This can be seen from the material of the work meeting hearing and the OJK budget in 2016 with the House of Representatives Commission XI.

19 www.ojk.go.id, 2016, Frequently Asked Questions Otoritas Jasa Keuangan, accessed 11 Juli 2016
}

similarity in authority, function, and responsibility over the internal audit function.

According to Arifin P. Soeriaatmadja, the accountability principle oriented to results means that every budget user is obligated to answer and explain the organizational performance on the success or failure of a program under his/her responsibility. 20 In answering and explaining the FSA's performance over its success or failure, the FSA preformed internal surveillance. Interested parties of this information are not just the Parliament but also the FSA itself in watching over its internal finance. Establishing surveillance through the Parliament and the Audit and Verification system explained above are efforts to realize the FSA's accountability in surveillance.

The proportionality principle is related with the balance between right and obligation of the nation's executor, the effort to preform surveillance over the FSA's Finance is the effort to realize this principle. The FSA institution has rights to collect funds from the financial industry as thoroughly related in the Governments Regulation No. 11 of 2014 regarding the FSA's Collection. The effort is used to fund the FSA's operational activity. In lieu to the FSA's activity, it certainly also has obligation to increase the public's and the collected financial institution's trust. The public's trust is due to the money FSA collected will be imposed to the people and it is FSA's duty to protect the people from

\footnotetext{
20 Arifin Soeriaatmadja dan Tim, Kompendium Bidang Hukum Keuangan Negara (sumber-Sumber Keuangan Negara), Jakarta: Badan Pembinaan Hukum Nasional Kementrian Hukum dan Ham, 2011, p. 10-11.
} 
financial institution's unhealthy practice. For that, the FSA performs surveillance internally beside the ones that is external in nature. This effort reflects FSA's realization of the proportionality principle in its collection surveillance.

\section{FSA's Collection Usage Report Mechanism}

As part of public accountability, the FSA conducted reporting activity over collection fund usage which is regulated in Chapter IX Law of the FSA regarding Reporting and Accountability. To financial report, the FSA is obligated to prepare semester and yearly report. The report period is from January $1^{\text {st }}$ until December $31^{\text {st }}$. For the arranging of financial report, the Commissioner Council appointed the FSA's accounting standards and policy. The yearly report is audited by the BPK or Public Accountant Office selected by the BPK. The activity report is divided into three which are the monthly, three-month, and yearly activity report.

Guy Peters as quoted by Adrian Sutedi explained the public policy Accountability. Public policy accountability is a principle that guarantees that every government establishment activity can be accounted for openly by the person responsible to all parties affected by the policy. This principle also guarantees that every government financial activities can be accounted for openly by the person responsible to all parties interested by the government's financial information. ${ }^{21}$ From the definition by Guy Peters and the explanation of FSA's reporting mechanism, the accountability principle in FSA's reporting mechanism is unquestionable. This report is divided into two which are the Financial and Activity report. The Financial report is divided also into the semester and yearly report. The activity report is divided into three which are the monthly, three-month, and yearly activity report. All reports have targets regulated in PDKOJ No. 1/PDK.01/2015 regarding the LKOJK. According to the explanation above it can be summarized that the Financial and Activity Reporting mechanism is a structured and scheduled activity to report all collection usage in the execution of activities by every branch in the FSA. The reporting mechanism is done vertically from the Budget Work and Realization Unit of the Directorate, Department, and Deputy Commissioner level. On the other hand, the FSA as the budget user reports its finance and activity to the public society (Parliament) and the President.

As explained above, the regulation about the reporting mechanism has guaranteed accountability of financial and activity reports by the FSA. The accountability principle also applied through the surveillance and management mechanism. Fulfilling the proportionality principle in its 2014 financial report showed that the FSA used its collected funds optimally which in turn showed optimal financial usage and compliance to the proportionality principle. The 2014 FSA Financial report showed funds up to Rp.117.176.545.778.00 stored into the National Cash, it is the FSA's unused

\footnotetext{
21 Adrian Sutedi, Implikasi Hukum atas Sumber Pembiayaan Daerah dalam Kerangka Otonomi Daerah, Jakarta: Sinar Grafika, 2009, p. 397.
} 
excessive funds. In 2015, FSA's 2015 financial report showed significant decrease in which the residual earnings is returned to the National Cash with the amount of Rp. 15,171,713,057.00. It showed FSA's goodwill in trying to fulfill its obligation as an institution that watches over the financial industry. The 2014 budget usage which is not optimal showed that the FSA didn't comply to the proportionality principle in which the right accepted by FSA is inappropriate to its obligation to run its activity according to the budget. However, in 2015 the FSA can be said to have complied with the proportionality principle because its return of funds to the National Cash has decreased greatly compared to the budget year of 2014. The decrease showed that the FSA tried to execute activities according to the task and function as budgeted and thus the funds has been absorbed optimally.

\section{CONCLUSION}

1. The FSA's financial status is that of the Nation's Financial when using collection. This is based on analysis on the definition of nation's financial according to Article 2 Act number 17 of 2003 regarding the Nation's Financial, which shows that FSA's finance complied with several definition of the Nation's Financial. The first of which is that the nation's duty to undertake the national government's general service task and paying third party bills; the second is the national income; the third is that the national/regional wealth which are managed independently or by other party in the form of money, stock, receivables, goods and other right that can be measured with money; the fourth is other parties' wealth possessed by the government to undertake governmental task and or public interest; the fifth is other parties' wealth earned using facilities given by the government. Regarding the Nation's Income, the FSA's collection management is analogous to BLU financial management having similarity which is the flexible an independent management, thus can be seen as an excepted national income which still can be considered as national income. According to the approach, the FSA complied with all approach elements of Object, Subject, Process, and Purpose. The FSA also a institution which financial is regulated by the Ministry of Finance because the FSA complies with the UBL definition in the Indonesian Republic Minister of Finance's Regulation Number 235/PMK.05/2011 regarding Other Agency's Accounting System and Financial Reporting. The FSA's Collection as a national finance also has a firm basis of Article 23A of the third amendment of the 1945 Constitution that states that Tax and others coercive collection for the nation's interest is regulated by law.

2. The Collection Management Mechanism of the FSA has complied with the Accountability Principle but not in the case of the FSA's Collection report as the budget absorption within the FSA's 2015 financial reporting showed the aversion of proportionality principle. 
As explained above, the principle demands the Nation's executive to realize the balance between rights and obligations that stick with it. The poor absorption of budget in 2014 showed that the FSA's obligation cannot be undertaken as planned in the previous budget year. The budget residue of 2014 is Rp. $117,176,545,778.00$ which is stored to the National Cash, showing that many of the FSA's obligation has not been done. In 2015 the FSA can be said to have complied with the proportionality principle because its return of funds to the National Cash has decreased greatly compared to the budget year of 2014 .

\section{BIBLIOGRAPHY}

\section{Books}

Hamdi, Muchlis, Naskah Akademik Rancangan UndangUndang(RUU) Tentang Hubungan Kewenangan Pemerintah Pusat dan Daerah, Jakarta: BPHN, 2011.

Rooseno dan Tim, Penelitian Hukum tentang Akuntabilitas Pendanaan Partai Politik Dalam Undang-Undang Nomor 2 Tahun 2011, Jakarta: Badan Pembinaan Hukum Nasional Kementrian Hukum dan HAM, 2014.

Soekanto, Soerjono, Pengantar Penelitian Hukum, Jakarta: Universitas Indonesia, 2008.

Soemardjono Maria S. W, Bahan Kuliah Metode Penelitian Hukum, Yogyakarta: Program Magister Hukum Universitas Gadjah Mada, 2011.

Soeriaatmadja, Arifin dan Tim, Kompendium Bidang Hukum Keuangan Negara (sumber-Sumber Keuangan Negara), Jakarta: Badan
Pembinaan Hukum Nasional Kementrian Hukum dan Ham, 2011.

Sutedi, Adrian, Implikasi Hukum atas Sumber Pembiayaan Daerah dalam Kerangka Otonomi Daerah, Jakarta: Sinar Grafika, 2009.

Tim UGM dan UI, Alternatif Struktur OJK yang Optimun, Yogyakarta: UGM dan UI, 2010.

\section{Dissertation}

Mochtar, Zainal Arifin, Penataan Lembaga Negara Independen Setelah Perubahan Undang-undang Dasar 1945, Disertasi, Yogyakarta: Universitas Gadjah Mada, 2012.

\section{Journal}

Mailinda Eka Yuniza dan Adrianto Dwi Nugroho, "Mekanisme Pertanggung Jawaban Anggaran Pendapatan dan Belanja Daerah", Jurnal Mimbar Hukum, 2011.

\section{Internet}

Wiyanti, Sri, 2012, Biaya operasional OJK 2014, http://www.merdeka.com, accessed 8 Oktober 2015.

Qorib, Fathan, "Pakar Pertanyakan Status Keuangan OJK”, http://www.hukumonline.com/, accessed 8 Oktober 2015.

Humas OJK, 2016, Frequently Asked Questions Otoritas Jasa Keuangan, www.ojk.go.id, accessed 11 Juli 2016

Yoz, Belum dibentuk, Independensi OJK diragukan, 2011 , www.hukumonline.com, accessed June 2016.

\section{Regulation}

Undang-Undang Dasar Negara Republik 
Indonesia Tahun 1945.

Undang-Undang No. 17 tahun 2003

tentang Keuangan Negara termuat

dalam Lembaran Negara Republik Indonesia Tahun 2003 Nomor 47.

Undang-Undang Nomor 21 tahun 2011 tentang Otoritas Jasa Keuangan termuat dalam Lembaran Negara Republik Indonesia Tahun 2011 Nomor 111.

Undang-Undang Nomor 1 tahun 2004 Tentang Perbendaharaan Negara termuat dalam Lembaran Negara Republik Indonesia Tahun 2004 Nomor 5.

Peraturan Pemerintah Republik Indonesia nomor 11 tahun 2014 tentang Pungutan oleh Otoritas Jasa Keuangan termuat dalam Lembaran Negara Republik Indonesia Tahun 2014 Nomor 33.

Peraturan Otoritas Jasa Keuangan tentang Tata Cara Pelaksanaan Pungutan oleh Otoritas Jasa Keuangan Nomor 3/POJK.02/2014 termuat dalam Lembaran Negara Republik Indonesia Tahun 2014 Nomor 66 